\title{
Comparison of Epidural and Spinal Anesthesia Techniques for Transurethral Resections: Ideal anesthesia technique for transurethral resections
}

\section{Comparação das técnicas anestésicas peridural e raquianestesia na ressecção transuretral: Técnica anestésica ideal para ressecção transuretral}

\author{
Elif Copuroglu ${ }^{1}$, Gonul Sagiroglu ${ }^{1}$, Beliz Bilgili ${ }^{2}$, Sevtap Hekimoglu ${ }^{1}$
}

1. Department of Anesthesiology and Reanimation, Trakya University Faculty of Medicine, Edirne, Turkey

2. Department of Anesthesiology and Reanimation, Marmara University School of Medicine, Istanbul, Turkey

This study was conducted in Trakya University Faculty of Medicine, Department of Anesthesiology and Reanimation.

Financial support: None.

Conflict of interest: The authors declare that they have no conflict of interest.

Correspondence address: Elif Copuroglu, Assist. Prof. Department of Anesthesiology and Reanimation, MD, Trakya University Faculty of Medicine, Edirne, 22030, Turkey. E-mail: elifcopuroglu@hotmail.com

Submitted: August 01, 2018. Accepted, after review: August 24, 2018.

\footnotetext{
ABSTRACT

Purpose: Transurethral resections (TUR) are commonly performed for elderly population who have multiple comorbidities which can cause intraoperative and postoperative complications. The type of anesthesia has an impact on patient outcome. The aim of the study is to compare the effectiveness of epidural and spinal anesthesia techniques for TUR. Methods: A total of 158 elective TUR cases were evaluated. The patients were randomized into 2 groups: Epidural anesthesia was applied to Group I ( $n=82$ ) and spinal anesthesia was applied to Group II ( $n=76)$. Both groups were compared for intraoperative hemodynamic parameters (mean arterial pressure, heart rate, peripheral oxygen saturations), total duration of hospital stay, perioperative complications, and satisfaction of the patients and surgeons. Results: The patients in the spinal anesthesia group experienced more frequent intraoperative hypotensive episodes during TUR ( $n=2$ vs. $n=10 ; p=0.026$ ) and had lower mean arterial pressure values for the first 30 minutes of anesthesia compared to epidural anesthesia group. The postoperative duration of bed stay was longer in the spinal anesthesia group $(402.96 \pm 49.61 \mathrm{~min})$ than the epidural anesthesia group $(205.91 \pm 28.27 \mathrm{~min})$ $(p<0.001)$. The patient satisfaction score was significantly higher in the epidural anesthesia group $(2.54 \pm 0.63)$ than the spinal anesthesia group $(2.23 \pm 1.22) \quad(p=0.04)$
} 
Comparison of Epidural and Spinal Anesthesia Techniques for Transurethral Resections: Ideal anesthesia technique for transurethral resections

Copuroglu E, et al

where as the surgeon satisfaction score were similar in both groups. Conclusion: Epidural anesthesia can be considered as an effective and safe technique for ambulatory interventions especially for elderly patients providing perioperative hemodynamic stability and postoperative early mobilization.

Key words: Epidural anesthesia. Spinal anesthesia. Transurethral resections.

\section{RESUMO}

Objetivo: As ressecções transuretais (RTU) são comumente realizadas em idosos com múltiplas comorbidades que podem causar complicações intra e pós-operatórias. 0 tipo de anestesia tem impacto no resultado do paciente. O objetivo do estudo é comparar a eficácia das técnicas de anestesia peridural e raquidiana para a RTU. Métodos: Um total de 158 casos de RTT eletivos foi avaliado. Os pacientes foram randomizados em dois grupos: anestesia peridural foi aplicada ao grupo I ( $n=82$ ) e raquianestesia no grupo II $(n=76)$. Ambos os grupos foram comparados quanto aos parâmetros hemodinâmicos intraoperatórios (pressão arterial média, frequência cardíaca, saturação periférica de oxigênio), tempo total de internação, complicações perioperatórias e satisfação dos pacientes e cirurgiões. Resultados: Os pacientes do grupo raquianestesia apresentaram episódios hipotensivos intraoperatórios mais frequentes durante a RTU ( $n=2$ vs. $n=10 ; p=0,026$ ) e tiveram valores de pressão arterial média menores nos primeiros 30 minutos de anestesia em comparação ao grupo de anestesia peridural. O tempo de permanência no leito pós-operatório foi maior no grupo raquianestesia $(402,96 \pm 49,61 \mathrm{~min})$ do que no grupo com anestesia peridural $(205,91 \pm 28,27 \mathrm{~min})(p<0,001)$. O escore de satisfação do paciente foi significativamente maior no grupo de anestesia peridural $(2,54 \pm 0,63)$ do que no grupo de raquianestesia $(2,23 \pm 1,22)(p=0,04)$, enquanto que, o grau de satisfação do cirurgião foi semelhante em ambos os grupos. Conclusão: A anestesia peridural pode ser considerada uma técnica eficaz e segura para intervenções ambulatoriais, especialmente em pacientes idosos, proporcionando estabilidade hemodinâmica perioperatória e mobilização precoce pós-operatória.

Descritores: Anestesia peridural. Raquianestesia. Ressecção transuretral.

\section{INTRODUCTION}

Transurethral resections are commonly performed for elderly population as an ambulatory surgery. Choosing the type of anesthesia is very important for anesthesiologists especially for the elderly patients who mostly have comorbidities, which can cause intraoperative and postoperative complications ${ }^{1}$. Compared to general anesthesia, because of being cost-effective and reduced need for post- 
Comparison of Epidural and Spinal Anesthesia Techniques for Transurethral Resections: Ideal anesthesia technique for transurethral resections

Copuroglu E, et al

operative analgesia, spinal and epidural anesthesia techniques are considered as good alternatives ${ }^{2}$. Furthermore, older patients often have comorbid conditions including chronic obstructive pulmonary disease, coronary heart disease, or diabetes mellitus thus making these patients good candidates for regional anesthesia3. Moreover, regional anesthesia is a good alternative since it allows the early detection of TUR syndrome and intraoperative complications such as bladder perforation ${ }^{4,5}$.

Spinal anesthesia has been widely used in transurethral resection surgeries due to its' easy application, low-dose local anesthetic requirements, rapid onset, and effective motor and sensory blockage ${ }^{6}$. Hence, complications such as intraoperative hypotension and bradycardia, postoperative headache, urinary retention, and transient neurological symptoms occur more frequently with spinal anesthesia ${ }^{3,7}$. Moreover, the lack of need for postoperative analgesia in outpatient interventions avoids the need for an epidural catheter. Therefore, a single dose of epidural anesthesia is a good alternative to spinal anesthesia ${ }^{8}$.

This prospective randomized study aims to compare the effectiveness of epidural and spinal anesthesia in terms of hemodynamic outcomes, patient and surgeon satisfactions, complications and side effects for transurethral resections.

\section{METHODS}

The present prospective, double-blinded randomized study was conducted in in a period of 18 months. Written informed consents were obtained from all patients. Patients aged between 18 and 75 years [American Society of Anesthesiologists (ASA) score of I to III] scheduled for transurethral resection procedures randomly selected into 2 groups: patients who received epidural anesthesia (group I) ( $n=82$ ); and those who received spinal anesthesia (group II) ( $n=76)$. Uncooperative patients, patients with severe liver or kidney failure, having a drug allergy or systemic or local infection at the interventional site, patients receiving anticoagulant therapy, and have bleeding disorders or platelet count less than 50×109/L, were excluded from the study.

After an initial intravenous (iv) infusion of $10 \mathrm{ml} / \mathrm{kg}$ of Ringer's lactate solution in 20 minutes, all patients were continuously infused with $5 \mathrm{ml} / \mathrm{kg} /$ hour Ringer's 
Comparison of Epidural and Spinal Anesthesia Techniques for Transurethral Resections: Ideal anesthesia technique for transurethral resections

Copuroglu E, et al

Lactate solution. Standard anesthesia monitoring such as intraoperative mean arterial pressures (SAP, DAP, MAP), heart rate (HR) and electrocardiography and peripheral oxygen saturations were applied. First measurements ( 0 minute) were used as preoperative baseline data. Perioperative MAP recordings were consequently performed in the $3,5,10,15,20,3045,60$, and 75 th minutes.

In the spinal anesthesia group, $2.5 \mathrm{ml}$ of $0.5 \%$ Bupivacaine $(12.5 \mathrm{mg})$ was administered into the subarachnoid space via L4-5 interspace with the use of 25-gauge Quincke needle. Patients in the epidural anesthesia group received $10 \mathrm{ml}$ of $0.5 \%$ Bupivacaine $(50 \mathrm{mg}$ ) by inserting 18-gauge Touhy needle through the L3-4 interspace into the epidural space using the loss of resistance (LOR) technique. Motor and sensory blocks were assessed by modified Bromage scale and pinprick test, respectively. The residence time of sensory blocks was recorded.

Subjects who were placed in the 20 degrees Fowler position during surgery received $3 \mathrm{~L} / \mathrm{min}$ supplementary oxygen via face-mask. Propofol infusion at $1 \mathrm{mg} / \mathrm{kg}$ for sedation was administered if needed. Pain was evaluated using visual analog scale (VAS). Additional analgesics were given to the patients who had intraoperative VAS score $\geq 4$. In case of hypotension (30\% or more decrease in MAP), crystalloid infusion rate was increased to $15-20 \mathrm{ml} / \mathrm{kg} / \mathrm{hour}$ and if hypotension could not be corrected, an iv bolus of $10 \mathrm{mg}$ ephedrine was infused. Additionally, bradycardia (heart rate less than 50 beats/min), nausea and vomiting were treated with iv bolus of $0.02 \mathrm{mg} / \mathrm{kg}$ atropine and $10 \mathrm{mg}$ of metoclopramide, respectively. Intraoperative propofol consumption was recorded. Postoperative durations of bed stay and length of hospital stay were also recorded. Four-point visual analogue scores were used for the assessment of postoperative patient ( $0=\mathrm{bad}, 1=$ moderate, $2=$ good, $3=$ very good) and surgeon satisfaction (1=very good, $2=$ good, $3=$ moderate, 4=bad). Postoperative pain levels were also evaluated with VAS, $8 \mathrm{mg}$ of lornoxicam (maximum dose of $24 \mathrm{mg}$ ) was administered iv to the patients with a VAS score $\geq 4$. Hypotension, bradycardia, nausea and vomiting, post-spinal headache, infection, itching, and neurological complications during hospitalizations were recorded. 
Comparison of Epidural and Spinal Anesthesia Techniques for Transurethral Resections: Ideal anesthesia technique for transurethral resections

Copuroglu E, et al

\section{Statistical analysis}

Normality distribution was checked using D'Agostino-Pearson test. Parametric data were tested with independent samples t-test and nonparametric data, and categorical data were analyzed using Mann-Whitney $U$ and chi-square tests, respectively. Data were expressed as mean \pm standard deviation or numbers and statistical analyes were performed using MedCalc(C) for Windows, version 12.7 (MedCalc Software, Os- tend, Belgium). A p value less than 0.05 was considered as statistically significant.

\section{RESULTS}

A total of 158 patients were included in the study. Patient demographics such as age, gender, weight and ASA classification were comparable in two groups (Table 1). In the spinal anesthesia group, MAP in $3 \mathrm{rd} \min (101.52 \pm 17.37 \mathrm{mmHg}$ vs $107.10 \pm 13.79 \mathrm{mmHg})$, in 5 th $\min (101.28 \pm 15.78 \mathrm{mmHg}$ vs $106.63 \pm 12.50 \mathrm{mmHg})$, in 10th $\min (94.60 \pm 13.07 \mathrm{mmHg}$ vs $107.88 \pm 53.94 \mathrm{mmHg})$, in 15 th $\min (93.16 \pm 16.65$ $\mathrm{mmHg}$ vs $99.27 \pm 20.85 \mathrm{mmHg})$ and in 30 th $\min (83.66 \pm 39.79 \mathrm{mmHg}$ vs $109.28 \pm 34.98$ $\mathrm{mmHg}$ ) were significantly lower than the epidural anesthesia group $(p=0.026, p=0.019$, $p=0.038, p=0.044, p=0.035$ respectively) (Figure 1). Furthermore, patients in the spinal anesthesia group experienced more frequent intraoperative hypotensive episodes during transurethral resections ( $n=2$ vs $n=10 ; p=0.026$ ).

Table 1 - Patient demographics

\begin{tabular}{lccc}
\hline Variables & $\begin{array}{c}\text { Group I } \\
{[\mathbf{n}=\mathbf{8 2}]}\end{array}$ & $\begin{array}{c}\text { Group II } \\
\text { [n=76] }\end{array}$ & P value \\
\hline Age (years) & $65.4 \pm 13.75$ & $66.02 \pm 11$ & 0.7 \\
\hline Sex (M/F) & $62 / 20$ & $64 / 12$ & 0.25 \\
\hline Height $(\mathrm{cm})$ & $168.75 \pm 6.45$ & $169.07 \pm 6.02$ & 0.74 \\
\hline Weight $(\mathrm{kg})$ & $74.18 \pm 11.98$ & $73.76 \pm 13.66$ & 0.83 \\
\hline ASA $(\mathrm{I} / \mathrm{II} / \mathrm{III})$ & $32 / 44 / 6$ & $19 / 46 / 11$ & $\mathrm{NA}$ \\
\hline
\end{tabular}

Values are median (range), absolute numbers, or median \pm standart derivation ASA; American Society of Anesthesiologists, Group I: Epidural, Group II: Spinal 


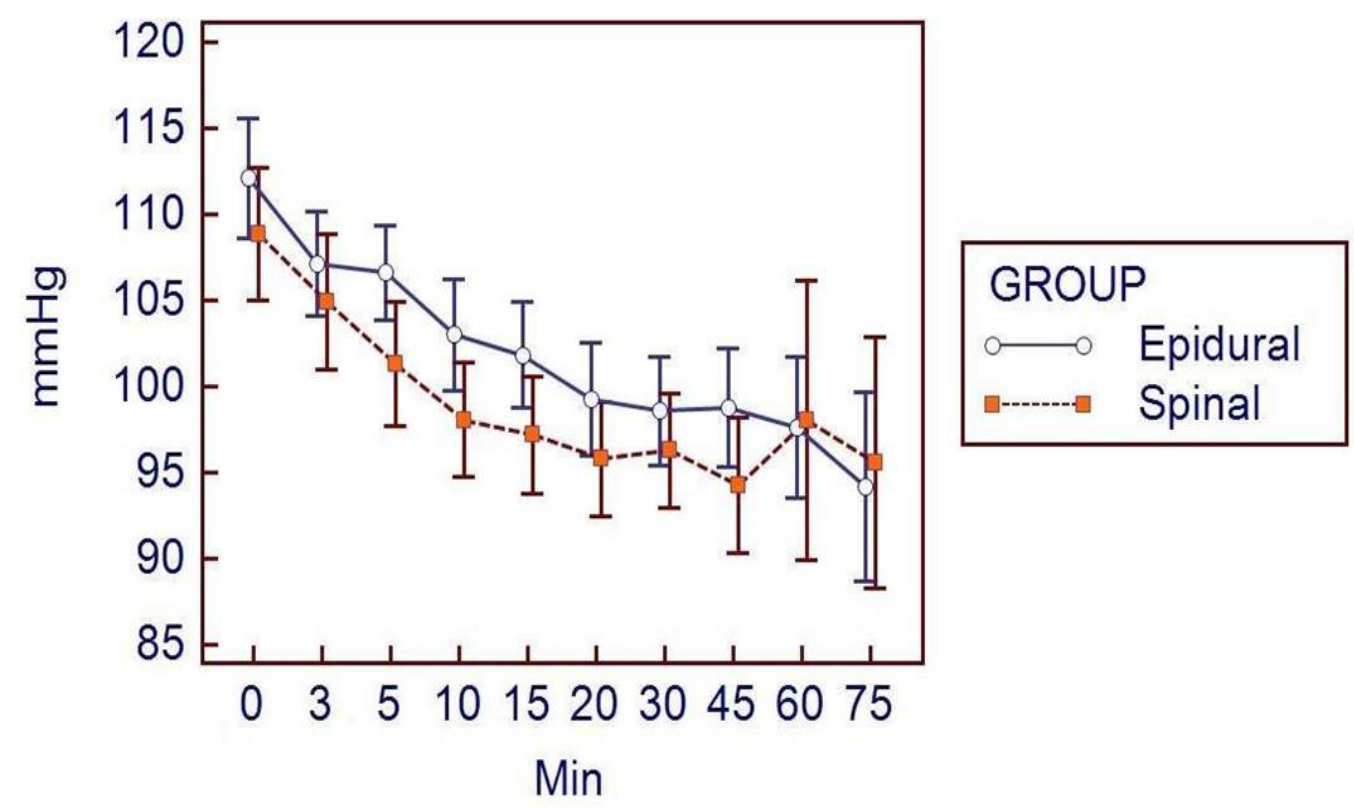

Figure 1 - Comparison of mean arterial pressures of the study groups over time.

Although insignificant, intraoperative bradycardia was observed more frequently in spinal anesthesia group than in epidural anesthesia group ( $n=7$ vs $n=11$, $p=0.12$ ). Occurrence of intraoperative respiratory depression was comparable in the two study groups ( $n=3$ vs $n=3$ ). Only 2 patients who were in the spinal anesthesia group had nausea. In the postoperative period, no patients experienced respiratory depression, headache, or nausea and vomiting.

The duration of surgery in the epidural anesthesia group $(56.70 \pm 21.25 \mathrm{~min})$ was similar with the spinal anesthesia group $(50.64 \pm 21.79 \mathrm{~min})(p=0.07)$. The length of hospital stay was comparable between the epidural and spinal anesthesia groups (44.48 \pm 22.74 hours vs $48.78 \pm 24.42$ hours, $p=0.25$, respectively). The postoperative duration of bed stay was longer in the spinal anesthesia group $(402.96 \pm 49.61 \mathrm{~min})$ than the epidural anesthesia group $(205.91 \pm 28.27 \mathrm{~min})(p<0.001)$. Intraoperative propofol consumption was $12.68 \pm 40.24 \mathrm{mg}$ in the epidural anesthesia group compared to $2.63 \pm 12.68 \mathrm{mg}$ in the spinal anesthesia group $(p=0.03$ ) (Table 2$)$. 
Table 2 - Perioperative and postoperative events

\begin{tabular}{lccc}
\hline \multicolumn{1}{c}{ Variables } & $\begin{array}{c}\text { Group I } \\
{[\mathbf{n}=82]}\end{array}$ & $\begin{array}{c}\text { Group II } \\
{[\mathbf{n = 7 6 ]}}\end{array}$ & P value \\
\hline Duration of surgery (min) & $56.70 \pm 21.25$ & $50.64 \pm 21.79$ & 0.07 \\
\hline $\begin{array}{l}\text { Length of hospital stay } \\
\text { (hours) }\end{array}$ & $44.48 \pm 22.74$ & $48.78 \pm 24.42$ & 0.25 \\
\hline $\begin{array}{l}\text { Duration of postoperative bed } \\
\text { stay (min) }\end{array}$ & $205.91 \pm 28.27$ & $402.96 \pm 49.61$ & $<0.001$ \\
\hline Propofol consumption (mg) & $12.68 \pm 40.24$ & $2.63 \pm 12.68$ & 0.03 \\
\hline
\end{tabular}

Values are median \pm standart derivation. Group I: Epidural, Group II: Spinal

Although the surgeon satisfaction scores were similar between the epidural and spinal anesthesia groups $(1.37 \pm 0.64$ vs $1.48 \pm 0.75, p=0.33$, respectively), the patient satisfaction score was significantly higher in the epidural anesthesia group $(2.54 \pm 0.63)$ than the spinal anesthesia group $(2.23 \pm 1.22)(p=0.04)$.

\section{DISCUSSION}

This study aimed to compare the effectiveness of spinal and epidural anesthesia techniques in elderly patients who underwent transurethral resection. Perioperative hemodynamic stability and shorter postoperative bed stay with epidural anesthesia make it the choice of anesthesia technique for elderly patients undergoing transurethral resection.

The spinal anesthesia group had a significantly lower MAP for the first 30 min of the anesthesia period than the epidural anesthesia group. The patients with spinal anesthesia experienced more perioperative hypotensive attack and bradycardia compared to the patients with epidural anesthesia. Mortality and morbidity related to anesthesia and surgery are higher in elderly patients compared to general population. Hemodynamic stability is one of the key components of perioperative anesthesia management in this patient population ${ }^{9}$. Hemodynamic instability in the perioperative period results in cardiovascular complications. Intraoperative hypotension is one of the most experienced factors associated with death related to anesthesia. Even short episodes of an intraoperative MAP of $<55 \mathrm{mmHg}$ are associated with acute kidney injury and myocardial injury after a non-cardiac surgery ${ }^{10,11}$. It's a well-known fact that 
Comparison of Epidural and Spinal Anesthesia Techniques for Transurethral Resections: Ideal anesthesia technique for transurethral resections

Copuroglu E, et al

hypotension and bradycardia are common side effects of spinal anesthesia ${ }^{12}$. Preexisting hypertension and a sensory block height exceeding T6 are major risk factors for the development of hypotension ${ }^{13}$. The occurrence of hypotension can be attenuated by administering low dose local anesthetic with fentanyl in elderly patients 14 .

Postoperative duration of bed stay was approximately two times longer in the spinal anesthesia group compared to epidural anesthesia group. Postoperative bed stay was reported longer in other studies comparing spinal and epidural anesthesia ${ }^{12,15}$. Prolonged postoperative immobilization is a risk factor for venous thromboembolism (VTE). Venous thromboembolism disproportionately affects the elderly. There is a linear increase in the prevalence of deep venous thrombosis and pulmonary embolism with age and for surgical patients, age over 60 years is associated with a high risk for postoperative VTE. Early postoperative mobilization is a crucial component in the prevention of postoperative VTE, which can result in pulmonary embolism and respiratory insufficiency ${ }^{16}$. Epidural anesthesia with a less pronounced and shorter duration of motor blockade has the advantage of early patient mobilization over spinal anesthesia ${ }^{17}$.

We further evaluated patient and surgeon satisfactions by using four-point assessment scale. In terms of patient satisfaction scores, patients in epidural arm of the study had significantly higher scores. On average, though more than $80 \%$ of patients in either group reported that they were satisfied. Similarly, Gupta et al. evaluated satisfaction scores of patient's, who underwent lower limb and inguinoscrotal region surgeries and showed that although statistical analyses demonstrated comparable results, it was found that $98 \%$ of patients who received spinal anesthesia and $96 \%$ of patients who received epidural anesthesia were satisfied from the technique used ${ }^{2}$. Additionally, study of Pollock et al., in which spinal and epidural anesthesia for outpatient knee arthroscopy were compared, reported that $92 \%$ patients of epidural group and $97 \%$ of spinal group were very satisfied from the corresponding techniques ${ }^{15}$. The present study further evaluated surgeon satisfaction and no significant differences were found, more than $80 \%$ of surgeons performed surgeries under either anesthetic techniques reported that they were satisfied. 
Comparison of Epidural and Spinal Anesthesia Techniques for Transurethral Resections: Ideal anesthesia technique for transurethral resections

Copuroglu E, et al

\section{CONCLUSION}

In the light of our findings, although both anesthetic techniques can be satisfactorily used for transurethral resection surgeries, epidural anesthesia can be considered as an effective and safe technique for ambulatory interventions especially for elderly patients providing perioperative hemodynamic stability and postoperative early mobilization.

\section{REFERENCES}

1. Lupei MI, Chipman JG, Beilman GJ, Oancea SC, Konia MR. The association between ASA status and other risk stratification models on postoperative intensive care unit outcomes. Anesth Analg. 2014;118(5):989-94.

2. Gupta A, Kaur S, Khetarpal R, Kaur H. Evaluation of spinal and epidural anaesthesia for day care surgery in lower limb and inguinoscrotal region. J AnaesthesiolClinPharmacol. 2011;27(1):62-6.

3. Kirdemir P, Topal M, Ozmen S, Altinisik U, Tuncer Perker T. Comparison of Spinal and Single Dose Epidural Anesthesia for Urological Procedures. Turkiye Klinikleri J Med Sci. 2009;29(2):405-9.

4. McGowan SW, Smith GF. Anaesthesia for transurethral prostatectomy. A comparison of spinal intradural analgesia with two methods of general anaesthesia. Anaesthesia. 1980;35(9):847-53.

5. Henny CP, Odoom JA, Ten Cate H, Ten Cate JW, Oosterhoff RJ, Dabhoiwala NF, et al. Effects of extradural bupivacaine on the haemostatic system. Br J Anaesth. 1986;58(3):301-5.

6. Foster RH, Markham A. Levobupivacaine: a review of its pharmacology and use as a local anaes- thetic. Drugs. 2000;59(3):551-79.

7. Schumann R, Rafique MB. Low-dose epidural anesthesia for cervical cerclage. Can J Anaest. 2003;50(4):424-5.

8. Ben-David B, Solomon E, Levin H, Admoni H, Goldik Z. Intrathecal fentanyl with small-dose di- lute bupivacaine: better anesthesia without prolonging recovery. AnesthAnalg. 1997;85(3):560-5.

9. Jin F, Chung F. Minimizing the perioperative adverse events in the elderly. BJA. 2001;87(4):608-24.

10.Lienhart $A$, Auroy $Y$, Pequignot $F$, Benhamou D, Warszawski J, Bovet $M$, et al. Survey of anesthesia-related mortality in France. Anesthesiology. 2006;105(6):1087-97.

11.Lonjaret L, Lairez $O$, Minville V, Geeraerts T. Optimal perioperative management of arterial blood pressure. Integr Blood Press Control. 2014;7:49-59.

12.Chinachoti T, Tritrakarn T. Prospective study of hypotension and bradycardia during spinal anesthesia with bupivacaine: incidence and risk factors, part two. J Med Assoc Thai. 2007;90(3):492-501.

13. Klasen J, Junger A, Hartmann B, Benson M, Jost A, Banzhaf A et al. Differing incidences of relevant hypotension with combined spinal-epidural anesthesia and spinal anesthesia. Anesth Analg 2003;96(5):1491-5. 
Comparison of Epidural and Spinal Anesthesia Techniques for Transurethral Resections:

Ideal anesthesia technique for transurethral resections

Copuroglu E, et al

14.Kararmaz A, Kaya S, Turhanoglu S, Ozyilmaz MA. Low-dose bupivacaine-fentanyl spinal anaesthesia for transurethral prostatectomy. Anaesthesia 2003;58(6):526-30.

15.Pollock JE, Mulroy MF, Bent E, Polissar NL. A comparison of two regional anesthetic techniques for outpatient knee arthroscopy. Anesth Analg. 2003;97(2):397-401.

16.Kim V, Spandorfer J. Epidemiology of venous thromboembolic disease. Emerg Med Clin North Am 2001;19(4):839-59.

17.Aromaa U, Linko K, Nieminen MT. Comparison of epidural and spinal blockade with $0.5 \%$ bupivacaine for transurethral surgery. Eur J Anaesthesiol. 1986;3(3):241-6. 